Article

\title{
The Saint-Honoré Carbonatite REE Zone, Québec, Canada: Combined Magmatic and Hydrothermal Processes
}

\author{
Alexandre Néron, Léo Paul Bédard *(i) and Damien Gaboury \\ Sciences de la Terre, LabMaTer, Université du Québec à Chicoutimi, Chicoutimi, QC G7H 2B1, Canada; \\ neron.alex@iosgeo.com (A.N.); dgaboury@uqac.ca (D.G.) \\ * Correspondence: pbedard@uqac.ca; Tel.: +1-418-815-5730
}

Received: 2 July 2018; Accepted: 5 September 2018; Published: 10 September 2018

\begin{abstract}
The Saint-Honoré carbonatite complex hosts a rare earth element (REE) deposit traditionally interpreted as being produced by late-stage hydrothermal fluids that leached REE from apatite or dolomite found in the early units and concentrated the REE in the late-stage units. New evidence from deeper units suggest that the Fe-carbonatite was mineralized by a combination of both magmatic and hydrothermal crystallization of rare earth minerals. The upper Fe-carbonatite has characteristics typical of hydrothermal mineralization-polycrystalline clusters hosting bastnäsite-(Ce), which crystallized radially from carbonate or barite crystals, as well as the presence of halite and silicification within strongly brecciated units. However, bastnäsite-(Ce) inclusions in primary magmatic barite crystals have also been identified deeper in the Fe-carbonatite (below $1000 \mathrm{~m}$ ), suggesting that primary crystallization of rare earth minerals occurred prior to hydrothermal leaching. Based on the intensity of hydrothermal brecciation, $\mathrm{Cl}$ depletion at depth and greater abundance of secondary fluid inclusions in carbonates in the upper levels, it is interpreted that hydrothermal activity was weaker in this deepest portion, thereby preserving the original magmatic textures. This early magmatic crystallization of rare earth minerals could be a significant factor in generating high-volume REE deposits. Crystallization of primary barite could be an important guide for REE exploration.
\end{abstract}

Keywords: carbonatite; rare earth elements; REE; deposit; hydrothermal; magmatic

\section{Introduction}

China has practically monopolized the production of rare earth elements (REE) over the last decades [1,2]. In 2009, the Chinese government established a restrictive quota on REE exportation and exploration for new sources of REE rapidly increased around the world. Future demand is expected to be strong as the market for green technologies, the main consumer of REE, is projected to increase [3-6]. Several geological processes or environments can produce economic REE concentrations [1,7-9]. However, carbonatites are REE-hosting rocks in which extractive metallurgy is better understood. According to Chakhmouradian and Zaitsev [9], 20 of the 50 most advanced REE extraction projects outside of China are found within igneous carbonate rocks, whereas most present-day or historical production has been from carbonatites or their weathered components.

Although carbonatites are known to have high natural concentrations of REE [10-12], in most cases these amounts are not sufficient enough to be economical $[6,9,13]$. Specific geological processes are required to enhance REE concentrations. Four major processes are commonly invoked. First, the precipitation of REE-bearing minerals, such as minerals of the bastnäsite group [(REE) $\left.\left(\mathrm{CO}_{3}\right) \mathrm{F}\right]$ or the parisite group $\left[(\mathrm{REE})_{2} \mathrm{Ca}\left(\mathrm{CO}_{3}\right)_{3} \mathrm{~F}_{2}\right]$, may occur from primary carbonatite magma forming idiomorphic crystals of REE minerals in the late-stage carbonatite [14-16]. Second, a carbonate melt 
phase can be separated from a silicate melt in order to generate a REE-rich carbonate melt and a REE-poor silicate phase [17-23]. Third, REE are remobilized and concentrated by hydrothermal solutions. A late hydrothermal solution can leach magmatic carbonates, apatite and sulphides to enrich late stage hydrothermal minerals in $\mathrm{Ba}, \mathrm{F}, \mathrm{SO}_{4}{ }^{2-}$, $\mathrm{Sr}, \mathrm{REE}$ and $\mathrm{Th}$ [24-26]. According to Mariano [15], in most carbonatites, "hydrothermal REE minerals occur in veinlets or as interstitial fillings, and appear as fine-grained polycrystalline clusters, commonly associated with barite, fluorite, hematite, quartz, strontianite and sulphides". This third process accounts for most REE concentration in carbonatites around the world. The fourth process is the result of chemical weathering of sub-surface carbonatite. As the carbonate minerals (calcite and dolomite) are easily dissolved, $\mathrm{Ca}$ and $\mathrm{Mg}$ are removed, thereby concentrating the less mobile elements, such as REE $[15,27,28]$. However, despite the great abundance of REE concentrated by hydrothermal processes in carbonatite, these concentrations rarely form high-tonnage economically viable deposits [15]. Early magmatic REE concentrations may therefore represent an important geological process favouring the formation of world-class REE deposits in carbonatites.

The Saint-Honoré carbonatite complex, exploited by Niobec Inc., hosts a niobium deposit as well as a REE zone in its central portion. Presently, only the niobium deposit is exploited. Previous studies of the Saint-Honoré REE zone [29,30] highlighted the role of a hydrothermal fluid in concentrating REE through fine-grained bastnäsite-(Ce) mineralization. In 2011-2012, this REE zone was drilled to a depth of $1250 \mathrm{~m}$, providing an opportunity to characterize the deeper portion of the REE zone. The Saint-Honoré carbonatite is classified as a world-class deposit with its total proven and inferred resources estimated at $1058.6 \mathrm{Mt}$ at $1.75 \%$ total rare earth elements (TREE) [31]. Based on its high tonnage, the REE mineralization of the Saint-Honoré carbonatite is not the usual, expected hydrothermal REE mineralization. The main objective of this study is to demonstrate the importance of the igneous preconcentration of the REE prior to hydrothermal enrichment to create a large deposit.

\section{Geological Setting}

The Saint-Honore carbonatite complex is located in the Saguenay region of Québec, Canada (Figure 1). This region is comprised of three petrographic domains [32,33]: (1) a gneiss complex (orthogneiss and paragneiss) deformed during the Hudsonian Orogeny (1735 Ma); (2) anorthosite and mangerite-charnockite batholiths dated to pre- to post-Grenvillian orogeny (935 Ma); and (3) younger calc-alkaline intrusions (which include the Saint-Honore alkaline complex) related to the St. Lawrence River Rift and the associated Saguenay Graben [34]. This latter extensional event provided crustal anisotropies that channeled alkaline magmatism, including the Saint-Honoré carbonatite [35]. An age of 565 Ma was obtained by Doig and Barton [36] for the alkaline complex. McCauland et al. [37] report an age of $571 \pm 5 \mathrm{Ma}$ from phlogopite in the carbonatite while Kamenetsky et al. [38] report a $\mathrm{Rb}-\mathrm{Sr}$ model age of $564 \pm 8 \mathrm{Ma}$ based on two points. A U-Pb age of $582.1 \pm 1.8 \mathrm{Ma}$ was obtained on baddeleyite from the carbonatite (Michael Higgins, UQAC, personal communication 2015). 


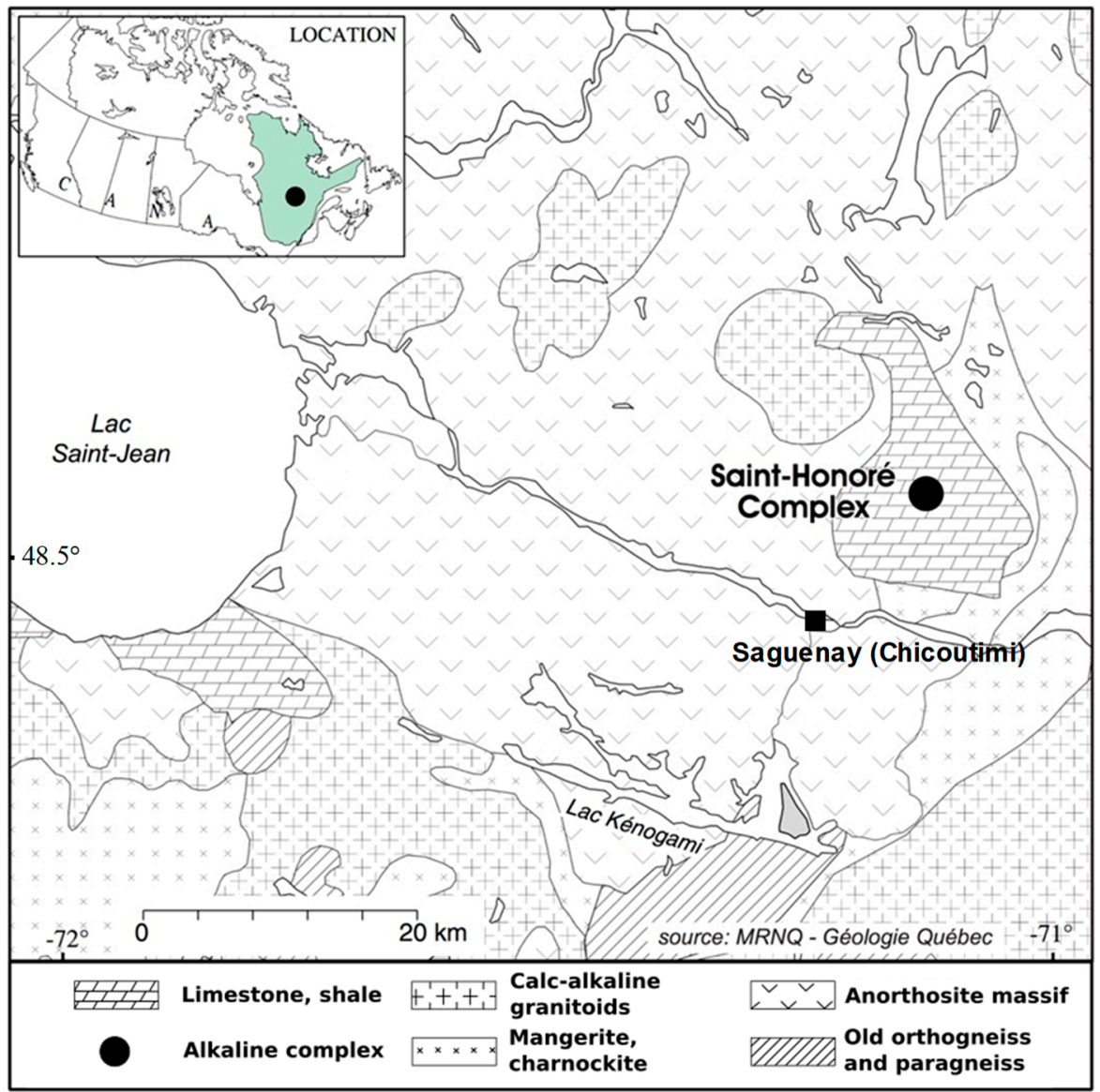

Figure 1. Study site location and local geology of the Saint-Honoré alkaline complex. Map modified from [39]. Note that the Saint-Honoré Complex is covered by the limestone and its location is interpreted from diamond drill hole surveys.

The Saint-Honoré alkaline complex is a vertical intrusion composed of a carbonatite core surrounded by alkaline silicate rocks. Fenitization is present in host rocks and is characterized by the metasomatism of pyroxenes into sodic amphiboles and carbonates, sericitization of plagioclase, and formation of many carbonatitic red to green veins [40]. The alkaline silicate units are mainly composed of nepheline syenite and younger alkaline syenite (all miaskitic, $\left(\mathrm{Na}_{2} \mathrm{O}+\mathrm{K}_{2} \mathrm{O}\right) / \mathrm{Al}_{2} \mathrm{O}_{3}$ $<1$ : molar proportion) [40]. Some xenoliths of alkaline syenite are observed in the carbonatitic part, suggesting that the carbonatite is younger than the syenites [40]. The carbonatitic units have an elliptical shape oriented north-east south-west (Figure 2) where the Fe-carbonatite is in the centre, enclosed by the Mg-carbonatite which is itself enclosed by the outer Ca-carbonatite. The main carbonatite crystallized at high temperatures $\left(1000-1150{ }^{\circ} \mathrm{C}\right.$, using the apatite-phlogopite geothermometer [30]), clearly suggesting a magmatic origin for the Mg-carbonatite. However, Fournier [30] obtained temperatures of 364 to $321^{\circ} \mathrm{C}$ for the weathered upper zone of the Fe-carbonatite (chlorite geothermometer). Crosscutting relationships show an evolution trend from Ca-carbonatite to Mg-carbonatite to Fe-carbonatite [40]. This evolution is in agreement with geochemical data: $\mathrm{MnO}$, which reflects the evolution of a carbonatite complex [12], increases from the calcitic rocks to the Fe-carbonatite (Table S1). Table 1 (from Fortin-Belanger [40]) shows partial geochemical analyses of the different units. Although these older results do not have the same quality as modern ones and many of these units are not available anymore, results are in agreement with modern ones and they are fit for the purpose [41]. La, Ce, and metal concentrations increase from older to younger units. This pattern is interpreted as the result of magmatic fractionation of these less compatible elements during the crystallization of carbonates [30]. An enrichment in REE can also be caused by the formation of 
immiscible carbonatitic liquids that capture most of trace and ultra-trace elements compatible with the carbonatite melt [17-23]. Furthermore, the REE deposit is hosted in the youngest and most evolved unit: the Fe-carbonatite. Yttrium, which behaves similarly to heavy rare earth elements (HREE), decreases with fractionation (Table 1), suggesting an early precipitation of HREE [40]. Only the light rare earth elements (LREE) are interpreted to have been concentrated by fractional crystallization to form the REE zone [29,30,40]. This fractionation between HREE and LREE is common in carbonatite and can be explained by the higher compatibility of HREE in early minerals such as apatite [42]. Compared to the carbonatitic units, the alkaline silicate units are significantly poorer in REE but richer in $\mathrm{Zr}$ (Table 1; [40]).

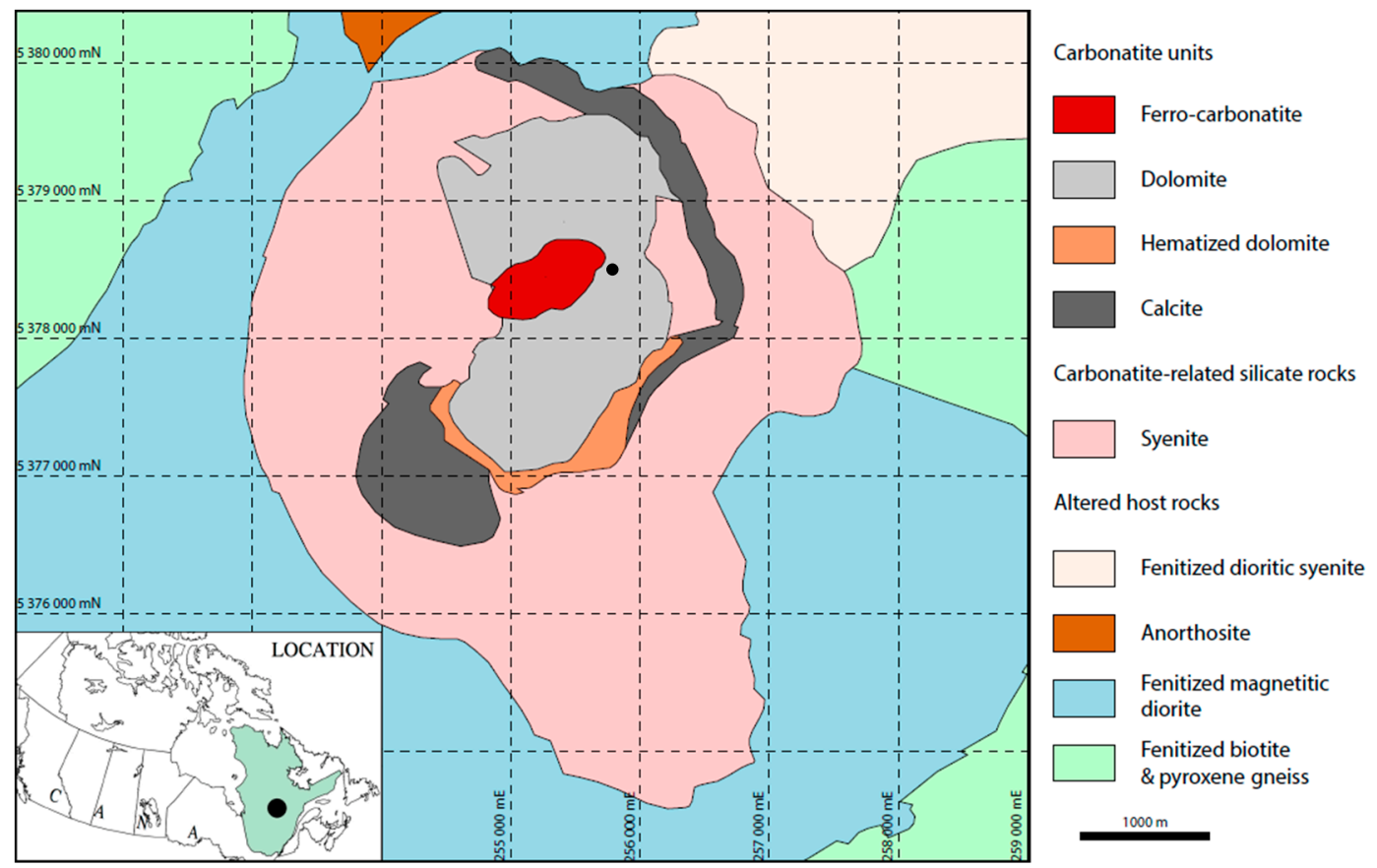

Figure 2. Geological map of the Saint-Honoré alkaline complex (below the Ordovician limestone). The location of deepest drill core used for geochemistry is localized by the black dot in the center of the ferro-carbonatite. The figure is modified from Niobec Inc. (Guillaume Matton, personal communication 2018) (UTM NAD 83 projection, Zone 19N).

Table 1. Representative analyses of different units within the Saint-Honoré complex (from [40]).

\begin{tabular}{cccccc}
\hline & Nepheline Syenite & Alkaline Syenite & Ca-Carbonatite & Mg-Carbonatite & Fe-Carbonatite \\
\hline $\mathrm{MnO}(\mu \mathrm{g} / \mathrm{g})$ & 3000 & 2000 & 5000 & 100,000 & $150,000-200,000$ \\
$\mathrm{La}(\mu \mathrm{g} / \mathrm{g})$ & 31 & 30 & 29 & 209 & 7044 \\
$\mathrm{Ce}(\mu \mathrm{g} / \mathrm{g})$ & $\mathrm{BDL}$ & 63 & 135 & 1102 & 29,715 \\
$\mathrm{Y}(\mu \mathrm{g} / \mathrm{g})$ & 64 & 1751 & 230 & 110 & 100 \\
$\mathrm{Zr}(\mu \mathrm{g} / \mathrm{g})$ & 838 & 22 & 2 & 37 & 56 \\
$\mathrm{~V}(\mu \mathrm{g} / \mathrm{g})$ & 56 & 11 & $\mathrm{BDL}$ & 11 & 90 \\
$\mathrm{Cr}(\mu \mathrm{g} / \mathrm{g})$ & 20 & 96 & 63 & 2 & 38 \\
$\mathrm{Co}(\mu \mathrm{g} / \mathrm{g})$ & 236 & 34 & 63 & 135 & 36 \\
$\mathrm{Cu}(\mu \mathrm{g} / \mathrm{g})$ & 35 & & & & 424 \\
\hline
\end{tabular}

Note: BDL: Below Detection Limit

The alkaline complex is covered by Ordovician limestone and the uppermost 60-120 m of the Fe-carbonatite were heavily weathered to an orange or red coloured carbonatite-possibly caused by the presence of free hematite-prior to deposition of the limestone [29,30].

According to previous studies [29], the principal economic REE minerals of the Saint-Honoré deposit are late-stage fluoro-carbonates that occur as needles of $0.5-2 \mu \mathrm{m}$ in diameter and up to $20 \mu \mathrm{m}$ in length. Although previous studies $[29,30]$ suggested that mineralization was related to a late-stage 
orthomagmatic hydrothermal system, they were limited to the first few hundreds of metres below ground level of weathered Fe-carbonatite.

\section{Materials and Methods}

\subsection{Petrographic Studies}

The macroscopic observations were performed by logging 19 deep drill cores located almost entirely in the REE zone. Microscopic observations were made from 100 polished thin sections taken from these drill cores, selected to cover representative vertical and lateral distributions. The thin sections were prepared by SGS Canada Inc. (Mississauga, ON, Canada) with oil-based lubricants and ethylene glycol to preserve the highly soluble minerals, such as halite, present in these rocks.

\subsection{Scanning Electron Microscope (SEM)}

Imaging was obtained through a Zeiss EVOMA15 HD scanning electron microscope (SEM) coupled with an energy dispersive spectrometer-silicon drift detector (EDS-SDD) from Oxford Instruments (Model X-Max 150, Wycombe, UK) from IOS Services Géoscientifiques Inc., Chicoutimi, QC, Canada. Back-scattered electron images, chemical mapping and phase identification were obtained with the following parameters: $40 \mu \mathrm{A}, 20 \mathrm{kV}$ with a working distance of $11.5 \mu \mathrm{m}$.

\subsection{Whole Rock Analysis}

Whole rock analyses presented in this study are from the deepest drill hole (located in Figure 2) as it is the most representative and there is a strong lateral continuity between the different drill holes. Whole rock analyses were generated in two main batches. The first batch was lower quality routine analysis and are not presented in this study. The deepest complete vertical drill hole has been reanalyzed by SGS Canada Inc. with the highest quality available to offer a complete vertical section. Major elements were determined by XRF and trace elements by ICP-MS following a multi-acid dissolution (quality controlled by SGS Canada with ORES-101 and GRE-2 reference materials). Chlorine was determined by titration. Finally, $\mathrm{C}$ and $\mathrm{S}$ were analyzed at LabMaTer (Université du Québec à Chicoutimi) using an elemental analyzer (Horiba, EMIA 220-V, Longjumeau, France) following the method of Bédard et al. [43] and WMS-1a and NBS-88a as reference materials [43,44]. All results were within the acceptable limits of uncertainty for our purposes [41].

\subsection{Trace Element Analysis of Minerals}

The trace element concentrations in minerals (Table S2) were determined by laser ablation inductively coupled plasma mass spectrometry (LA-ICP-MS; laser: M50e, Resonetics, Nahsua, NH, USA; mass spectrometer: Agilent 7700x, Santa Clara, CA, USA) at LabMaTer (Université du Québec à Chicoutimi). The following parameters were used: beam size of $33-50 \mu \mathrm{m}$, frequency of $10 \mathrm{~Hz}$, speed of $30 \mu \mathrm{m} / \mathrm{s}$ and a fluence of $2-5 \mathrm{~J} / \mathrm{cm}^{2}$. For all measurements, certified reference materials were used: NIST-610 [45,46] and MAPS-4 [47,48] for apatite; NIST-610, MACS-3 [48,49], GSE-1g [47,50] for carbonates; MAPS-4 [47,48] and CMP-1 (unreleased Mountain Pass reference material from the USGS [51]) for barite, bastnäsite-(Ce) and monazite-(Ce). Reference material values were taken from GeoREM database [52]. The internal standard was ${ }^{44} \mathrm{Ca}$ for apatite and carbonates, ${ }^{34} \mathrm{~S}$ for barite, ${ }^{140} \mathrm{Ce}$ for bastnäsite-(Ce) (as determined from previous microprobe determination at McGill University) and ${ }^{31} \mathrm{P}$ for monazite-(Ce). The isotopes monitored were ${ }^{6} \mathrm{Li},{ }^{23} \mathrm{Na},{ }^{24} \mathrm{Mg},{ }^{29} \mathrm{Si},{ }^{31} \mathrm{P},{ }^{33} \mathrm{~S},{ }^{34} \mathrm{~S},{ }^{37} \mathrm{Cl},{ }^{39} \mathrm{~K},{ }^{44} \mathrm{Ca}$, ${ }^{46} \mathrm{Ti},{ }^{47} \mathrm{Ti},{ }^{56} \mathrm{Fe},{ }^{57} \mathrm{Fe},{ }^{88} \mathrm{Sr},{ }^{89} \mathrm{Y},{ }^{135} \mathrm{Ba},{ }^{136} \mathrm{Ba},{ }^{137} \mathrm{Ba},{ }^{139} \mathrm{La},{ }^{140} \mathrm{Ce},{ }^{141} \mathrm{Pr},{ }^{144} \mathrm{Nd},{ }^{147} \mathrm{Sm},{ }^{151} \mathrm{Eu},{ }^{153} \mathrm{Eu},{ }^{157} \mathrm{Gd}$, ${ }^{158} \mathrm{Gd},{ }^{163} \mathrm{Dy},{ }^{165} \mathrm{Ho},{ }^{166} \mathrm{Er},{ }^{169} \mathrm{Tm},{ }^{173} \mathrm{Yb},{ }^{175} \mathrm{Lu},{ }^{176} \mathrm{Lu},{ }^{179} \mathrm{Hf},{ }^{180} \mathrm{Hf},{ }^{208} \mathrm{~Pb}$. The data was reduced with the Iolite software $[53,54]$. Minute mineral inclusions were excluded whenever possible, although, some sub- $\mu \mathrm{m}$ REE-fluoro-carbonates could not be avoided in some of the barite crystals (Table S2). 


\section{Results}

\subsection{Petrography of the Fe-Carbonatite}

The upper $80 \mathrm{~m}$ were previously described [29,30] as a sub-lateritic carbonatite, rich in chlorite and hematite. This heavy alteration is interpreted to be the result of past tropical climate and/or sea infiltration, as suggested by the presence of the Ordovician limestone on top of the carbonatite (Figure 3). As the main objective of this paper is to present the magmatic and hydrothermal components associated with the REE mineral crystallization, the weathered uppermost section of the deposit is not considered further except for comparative purposes.

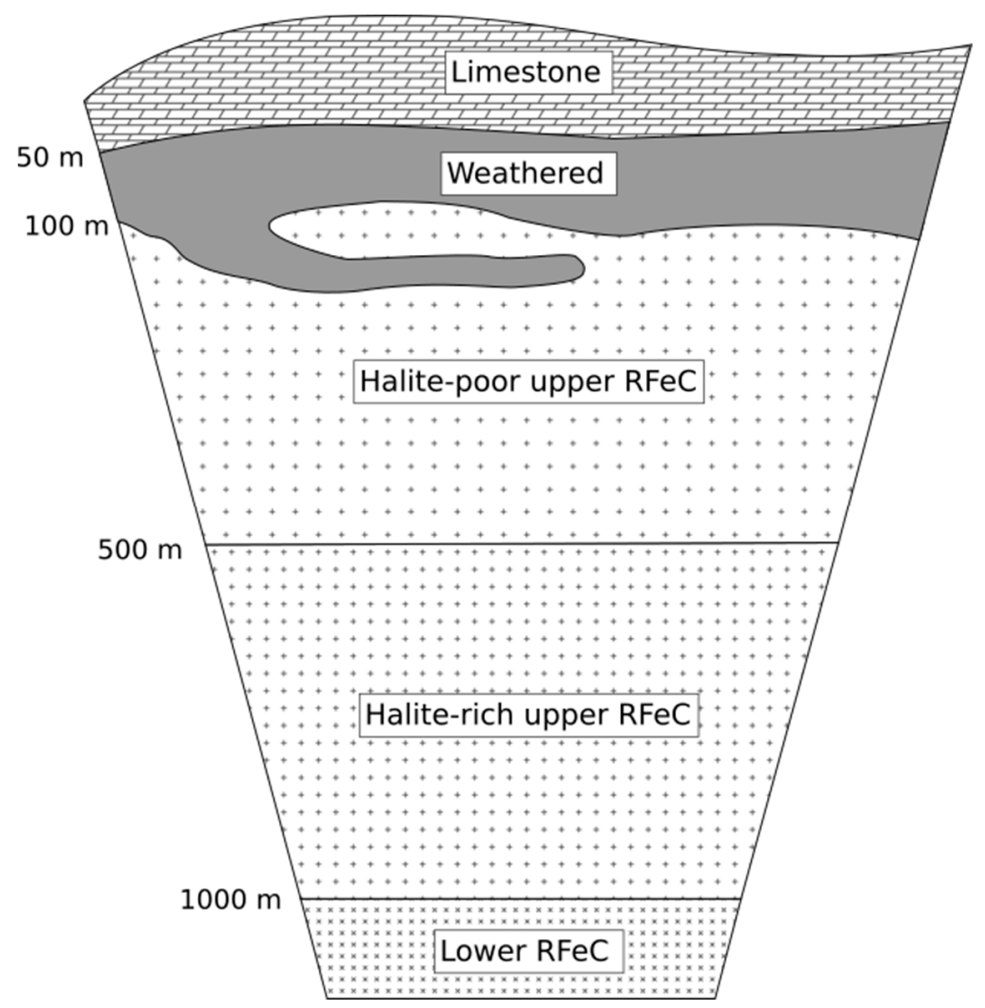

Figure 3. Schematic vertical cross section of the Saint-Honoré REE zone. RFeC $=$ REE-rich Fe-carbonatite.

The Fe-carbonatite is divided into two units: REE-poor Fe-carbonatite (PFeC) and REE-rich Fe-carbonatite (RFeC). Spatially, the RFeC is surrounded by the PFeC, and centimetre- to metre-scale crosscutting injections of the $\mathrm{RFeC}$ into the $\mathrm{PFeC}$ indicate that the $\mathrm{RFeC}$ represents a later stage than the PFeC. Considering that the REE-poor Fe-carbonatite does not hold important mineralization or critical information, it is not further discussed.

\section{REE-Rich Fe-Carbonatite (RFeC)}

This unit is the main host of REE minerals and consequently the focus of this study. At a macroscopic scale, the $\mathrm{RFeC}$ is primarily composed of carbonates (dolomite, dolomite with ankerite rim, ankerite, with minor amounts of calcite and siderite), barite, and purple polycrystalline clusters hosting REE mineralization (Figure 4D). Halite, quartz, pyrite, apatite, Nb-rutile, and thorianite are the minor phases with varying abundance from cluster to cluster. They do not show alteration and are interpreted to be hydrothermal. Two end-member textures are present: massive coarse-grained carbonatite (Figure 4D) and fine-grained hydraulic breccia (Figure 4A). Some of the contacts between 
the massive and brecciated carbonatite textures are sharp whereas others are gradual on the scale of a few centimetres or metres.

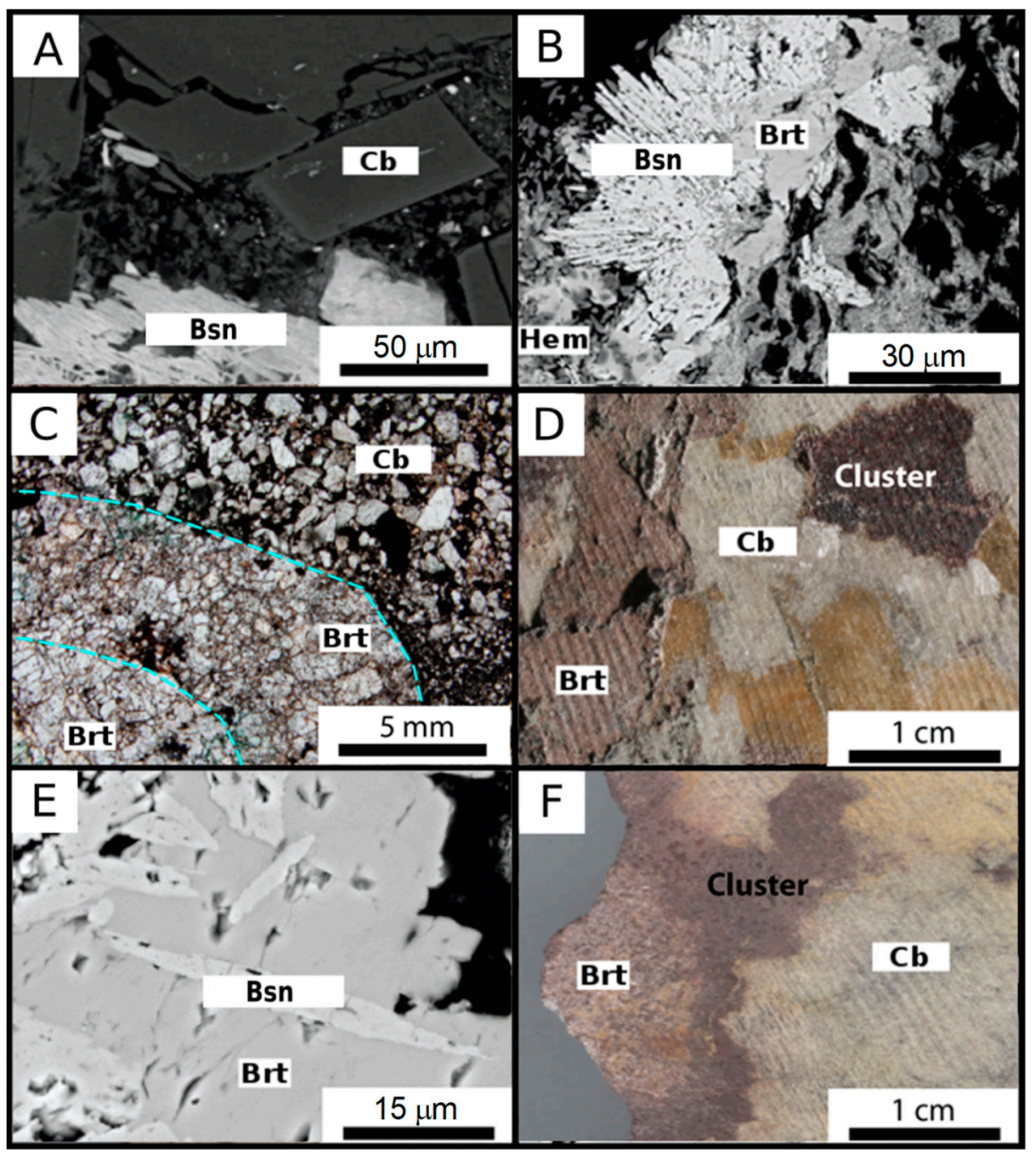

Figure 4. Selected images of the REE mineralization ordered by increasing depth: (A) Scanning electron microscope (SEM) image of low-intensity hydraulic breccia as suggested by the carbonate puzzle-shaped clasts (approximate depth: $235 \mathrm{~m}$ ); (B) SEM image of a polycrystalline cluster showing an ameboidal shape, radial bastnäsite-(Ce), monazite-(Ce), barite, carbonate, and hematite (approximate depth: $381 \mathrm{~m}$ ); (C) Photomicrograph (polarized natural light) of a large barite crystal showing a sharp pseudo-hexagonal shape (euhedral) with a pristine core, the external dashed line highlight the barite edge while the internal dashed line separate the recrystallized outer rim from the pristine core (approximate depth: $500 \mathrm{~m}$ ); (D) Photograph from the recovered drill core showing REE-rich Fe-carbonatite with purple polycrystalline clusters hosting the REE minerals; the buff coloration in the lower right-hand side of the photograph appears on carbonates after a few days of exposure to air and humidity (approximate depth: $500 \mathrm{~m}$ ); (E) SEM image of bastnäsite-(Ce) inclusions in a barite crystal suggesting early crystallization of REE minerals or co-crystallization of barite and bastnäsite-(Ce) (and parisite-(Ce)) (approximate depth: $910 \mathrm{~m}$ ); (F) Photograph from the recovered drill core showing barite with a pristine core and an altered rim (approximate depth: $1100 \mathrm{~m}$ ). Cb= carbonate, Brt = barite, Bsn = bastänasite-(Ce), Hem = hematite. These images are representative of all drill cores and not only the deepest one used for geochemistry.

The coarse-grained massive texture is composed of millimetre- to centimetre-sized carbonates, purple polycrystalline clusters hosting the REE mineral (bastnäsite-(Ce) and monazite-(Ce)) and barite 
in varying proportions. The carbonates, mainly dolomite and ankerite, are primary minerals, but exhibiting in certain places, late and locally low to medium recrystallization and/or brecciation. Some calcite crystals have an alteration rim of Fe-rich carbonate, which is siderite (Figure 5A).

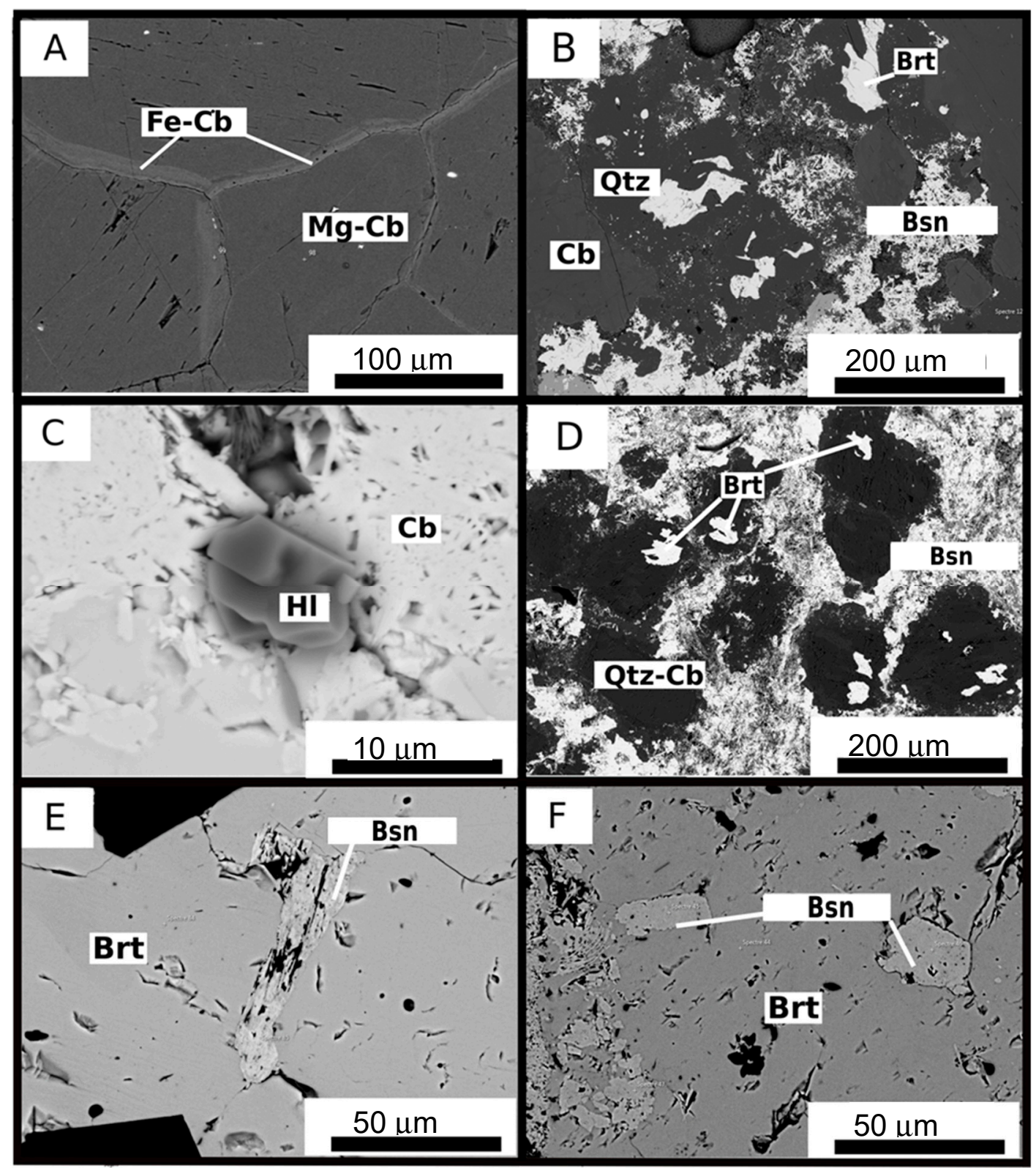

Figure 5. Selected SEM images of barite, carbonates, and halite by increasing depth: (A) Dolomite $(\mathrm{Mg}-\mathrm{Cb})$ with ankerite $(\mathrm{Fe}-\mathrm{Cb})$ rims from a depth of $350 \mathrm{~m}$; (B) Relic barite crystals showing dissolution in quartz and calcite in a REE-fluorocarbonate matrix from a depth of about $400 \mathrm{~m}$; (C) A small halite (Hl) crystal with carbonates from a depth of about $400 \mathrm{~m}$; (D) similar texture than b) from a depth of about $650 \mathrm{~m}$; (E) Barite from a depth of about $800 \mathrm{~m}$ with elongated bastnäsite-(Ce) crystal; (F) Barite from deeper than (B,D) (about $1100 \mathrm{~m}$ ) with $50 \mu \mathrm{m}$ bastnäsite-(Ce) inclusions, some of which are subidiomorph. $\mathrm{Cb}=$ carbonate; $\mathrm{Mg}-\mathrm{Cb}=$ dolomite; $\mathrm{Fe}-\mathrm{Cb}=$ ankerite; $\mathrm{Brt}=$ barite; Bsn = REEbastänasite-(Ce); Hem = hematite; $\mathrm{HI}=$ halite; Qtz = quartz. These images are representative of all drill cores and not only the deepest one used for geochemistry.

The barite crystals are, in general, finely recrystallized, but minor amounts of crystals exhibit a relict core of primary barite and have the shape of euhedral primary barite (Figure 4C,F). Moreover, 
such large barite crystals show homogeneous extinction suggesting they were a single euhedral large crystal (Figure 4C). Other barite crystals exhibit dissolution patterns associated with quartz and carbonate (Figure 5B,D) and halite (Figure 5C). The solubility of barite is known to increase in the presence of $\mathrm{Cl}^{-}$in fluids [55].

The following minerals have been observed in clusters: REE fluoro-carbonates (bastnäsite-(Ce), parisite, synchysite), monazite-(Ce), hematite, quartz, halite, barite, dolomite, and ankerite. However, not all of these minerals are present in all clusters. The clusters are generally ameboidal in shape and interstitial to the carbonates (Figure 4D,B). In these clusters, electron microscopy reveals that the barite exhibits a resorbed texture (Figure 5D), associated with the presence of halite $\left(\mathrm{Cl}^{-}\right)$and /or silicification. Silicification is common in the hydrothermal REE mineralization of carbonatites [56]. Hexagonal quartz crystals are locally present with barite suggesting it may be synchronous with silicification. The REE fluoro-carbonates are present primarily as bastnäsite-(Ce) in the form of fine needles (5-20 $\mu \mathrm{m}$ in length; Figure 4A,B). The fluoro-carbonates are usually crystallized radially from the edge of a carbonate or a resorbed barite (Figure 4B). Some overgrowth of bastnäsite-(Ce) has been observed from the core (parisite-(Ce)) to the rim (bastnäsite-(Ce)). The REE fluoro-carbonates are mainly present in the form of bastnäsite- $(\mathrm{Ce})\left[(\mathrm{Ce}, \mathrm{La}) \mathrm{CO}_{3} \mathrm{~F}\right]$ and the composition varies from parisite $\left[\mathrm{Ca}(\mathrm{Ce}, \mathrm{La})_{2}\left(\mathrm{CO}_{3}\right)_{3} \mathrm{~F}_{2}\right]$ or synchisite $\left[\mathrm{Ca}(\mathrm{Ce}, \mathrm{La})\left(\mathrm{CO}_{3}\right)_{2} \mathrm{~F}\right]$ to bastnäsite- $(\mathrm{Ce})$. The monazite- $(\mathrm{Ce})$ $\left[(\mathrm{La}, \mathrm{Ce}, \mathrm{Nd}) \mathrm{PO}_{4}\right]$, also found in the form of needles, is even smaller (less than $1 \mu \mathrm{m}$ in length) and is interstitial to other minerals. Usually, the monazite-(Ce) is associated with $\mu \mathrm{m}$-sized hematite.

The size of clasts within the brecciated unit is variable suggesting a variation of brecciation intensity. The breccia is also mineralized with REE. The clasts are composed of carbonate and barite, implying that they were both present prior to the brecciation. In thin sections where the brecciation intensity is low, the clasts can usually be fit together into their initial shape similar to a puzzle (jigsaw texture), suggesting hydraulic brecciation [57] (Figure 4A). Bastnäsite-(Ce) and monazite-(Ce), the most common REE minerals in the breccia, usually crystallize radially from the clasts or from the edge of the breccia as an overprint. Furthermore, no early clasts of REE minerals are observed, suggesting that the mineralization occurred post-brecciation. The transportation distance of clasts appears to be relatively short, according to the sharp angles and sizes of these clasts $(\mathrm{mm}$ to $\mathrm{cm})$.

An infiltration by surficial water is interpreted to have occurred in the upper $250 \mathrm{~m}$ of the carbonatite [30]. In this interval, halite, a highly soluble mineral, is completely absent. Additionally, barite is significantly less abundant and almost absent from the polycrystalline clusters. This observation could be explained by the relative solubility of barite in a Cl-rich fluid [55], as suggested by the presence of halite. The clusters of this upper section exhibit a porosity of $3-10 \%$ while there is no observable porosity in the deeper zone. Furthermore, interstitial minerals of the chlorite group in this section are observed in dissolved carbonates.

In the deepest drilled portion of the Saint-Honore Fe-carbonatite (more than $1000 \mathrm{~m}$ below the surface), there are several important textural and mineralogical variations. First, grain size is significantly larger than in the upper zone. Some crystals can reach up to $10 \mathrm{~cm}$ in length. Furthermore, in some places, barite, which is mostly euhedral to sub-euhedral, exhibits a zoned pattern featuring a pristine core and an altered rim composed of the cluster assemblage (Figure 4F). The observed breccia has only large and angular clasts, suggesting that only low-intensity brecciation is present in the deepest zone. Finally, barite from the deeper part of the deposit show bastnäsite-(Ce) and monazite-(Ce) inclusions implying early co-crystallization of barite and fluoro-carbonates (Figures $4 \mathrm{E}$ and 5E,F; Table S2). The minerals of the apatite group in the RFeC occurs in cm-scale stringers that crosscut all other minerals and units. In the $\mathrm{PFeC}$, the minerals of the apatite group are reddish and their textures suggest a replacement of the carbonates.

\subsection{Geochemistry of the Fe-Carbonatite}

For this section, only the deepest drill core has been considered as there is a strong lateral continuity. In a Ca-Mg-Fe classification diagram [58], most samples (Table S1) from Saint-Honoré fall 
within the Fe-carbonatite field (Figure 6). A linear trend exists between the Ca and Fe concentrations as the $\mathrm{Mg}$ concentration is relatively constant as shown in Figure 6. This type of trend is usually interpreted as being the result of a magmatic evolution [15], however this evolution trend does not show any relation with depth. There is no geochemical evolution trend with depth for the major elements as suggested by $\mathrm{SiO}_{2}, \mathrm{Al}_{2} \mathrm{O}_{3}$, and $\mathrm{K}_{2} \mathrm{O}+\mathrm{Na}_{2} \mathrm{O}$ (Figure 7) except for the weathering in the first $250 \mathrm{~m}$. The strongly-weathered, uppermost portion (upper $250 \mathrm{~m}$ ) of the Fe-carbonatite is characterized by relatively higher concentrations of $\mathrm{SiO}_{2}, \mathrm{Al}_{2} \mathrm{O}_{3}$, and $\mathrm{K}_{2} \mathrm{O}+\mathrm{Na}_{2} \mathrm{O}$ (Figure 7), corresponding to the presence of phlogopite [29,30] and chlorite [29].

The $\mathrm{Cl}$ concentrations (Table S1) vary from $0.02 \%$ to $0.43 \%$ and $\mathrm{BaO}$ from $0.03 \%$ to $13.96 \%$. Overall, $\mathrm{Cl}$ and $\mathrm{BaO}$ vary significantly with depth (Figure 8): $\mathrm{Cl}$ decrease while $\mathrm{BaO}$ increase with depth except for the weathered upper $250 \mathrm{~m}$ (Figure 8). It reflects a decrease in halite and an increase in barite proportion with depth. This relationship is in agreement with petrographic observations suggesting barite resorption was induced by a Cl-rich fluid in the upper zone [55]. The RFeC of Saint-Honoré has a $\mathrm{BaO} / \mathrm{SrO}$ ratio ranging from 4 to $58(>>1)$. Additionally, the uppermost $250 \mathrm{~m}$ portion is essentially depleted in $\mathrm{Cl}$ and $\mathrm{BaO}$ (Figure 8 ), reflecting the preferential weathering of more soluble minerals, such as halite and barite. The presence of halite below $250 \mathrm{~m}$ (Figure 8) suggests minimal interaction with surficial water at depth.

The abundance of $\mathrm{Cl}$ and $\mathrm{BaO}$ is anomalously high compared to the Woolley and Kempe [10] average $\mathrm{Cl}(0.02 \%)$ and $\mathrm{BaO}(0.88 \%)$ concentrations in Fe-carbonatite. In most Fe-carbonatite samples, no primary barite is observed because $\mathrm{Ba}$ is substituted in calcite, dolomite, and ankerite [12]. Although Woolley and Kempe [10] also documented high-BaO Fe-carbonatite with 9.6 to 20.6\% BaO (interpreted as being related to barite crystallization), they excluded these anomalous data from their calculation of "ordinary" Fe-carbonatite.

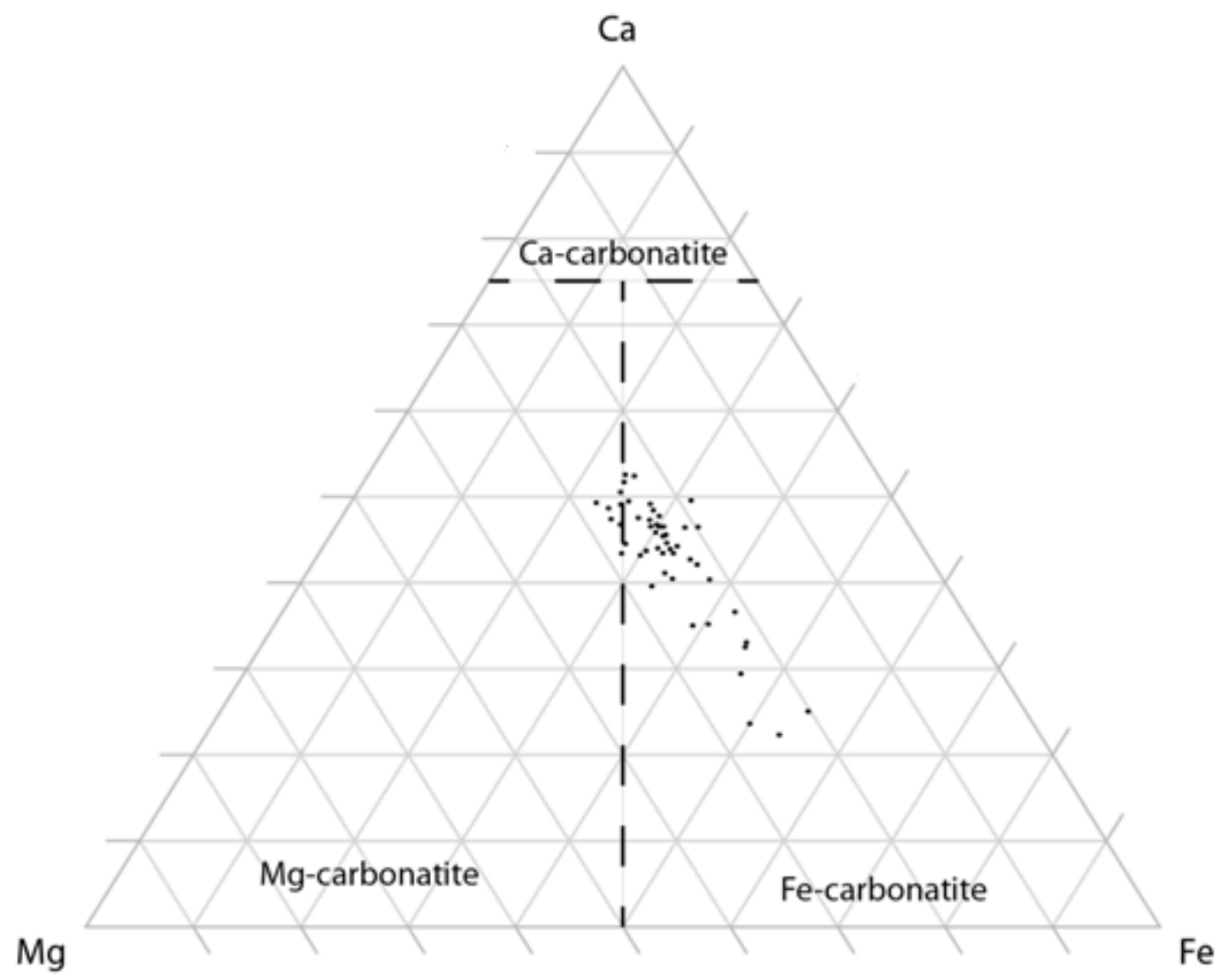

Figure 6. Mg-Ca-Fe classification diagram of ferro-carbonatite [58] for Saint-Honoré REE deposit samples (Table S1 some points overlap). 


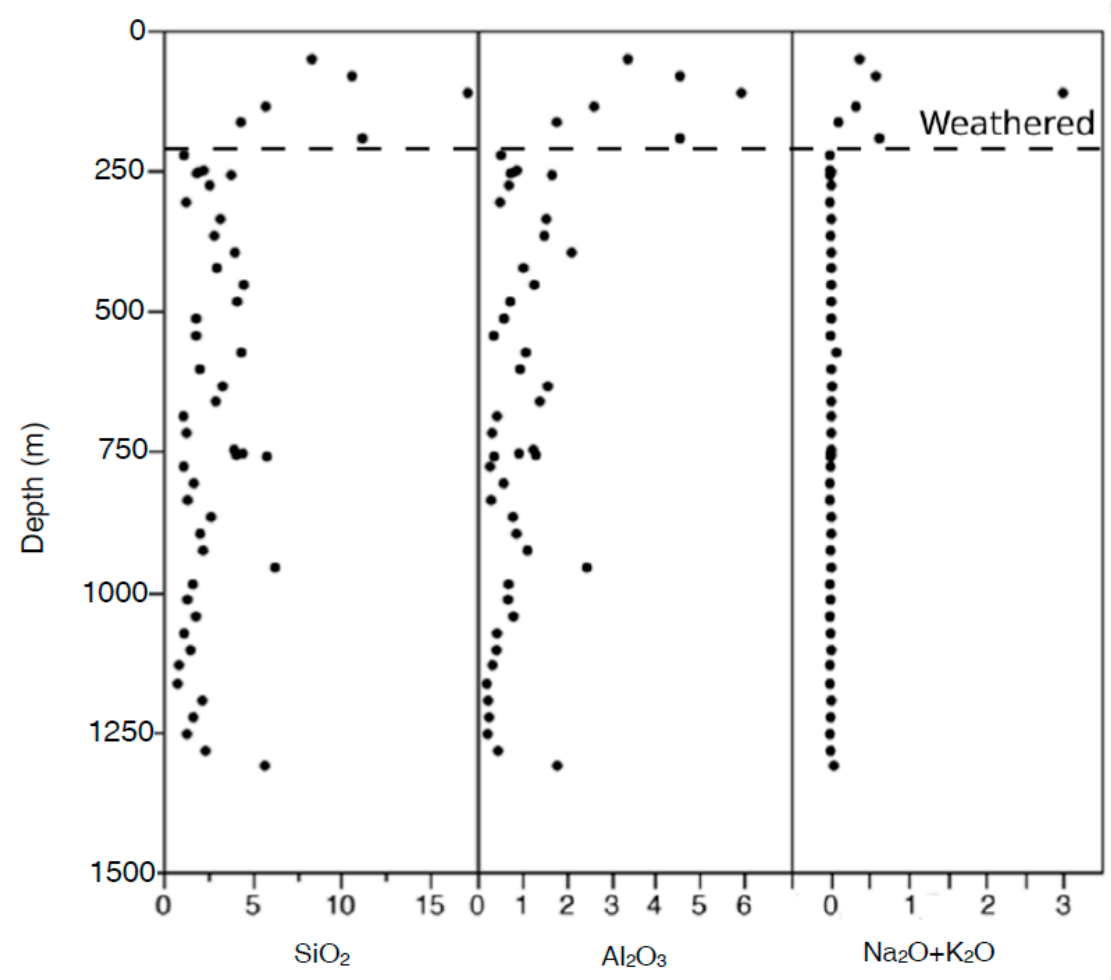

Figure 7. Abundance of silica, aluminium and potassium (wt \%) as a function of depth within the Saint-Honoré Fe-carbonatite. Note that the uppermost $250 \mathrm{~m}$ are strongly weathered.

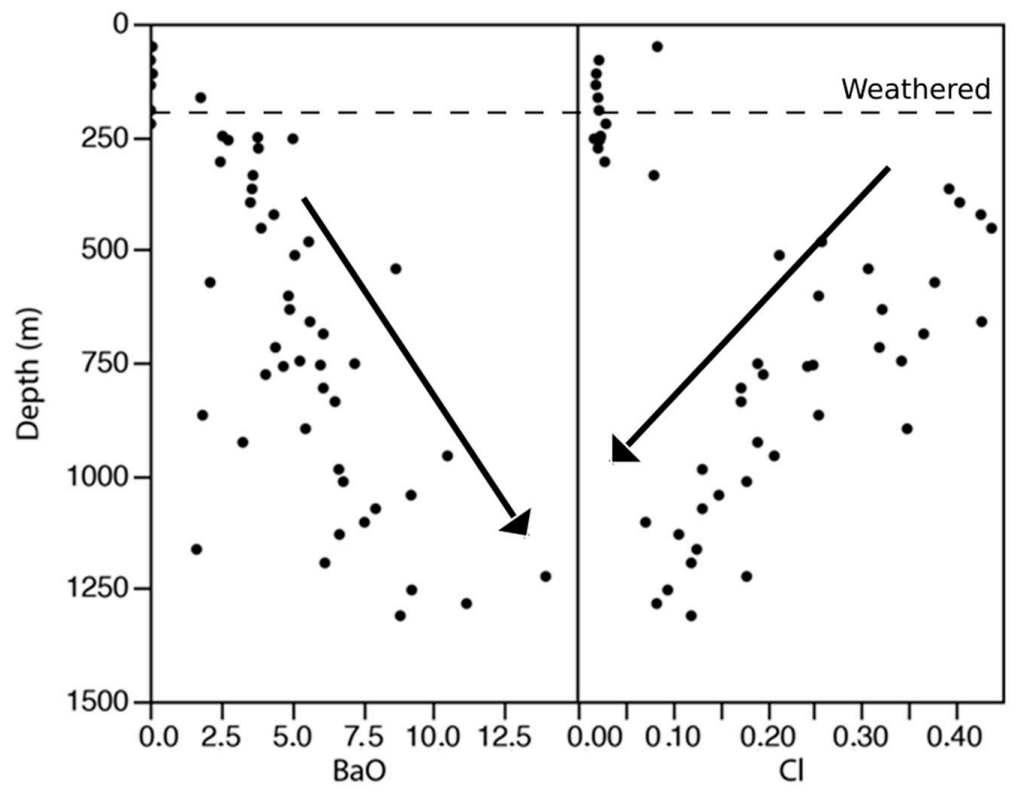

Figure 8. $\mathrm{BaO}$ and $\mathrm{Cl}$ (in wt \%) as a function of depth within the Saint-Honoré Fe-carbonatite. Note that the uppermost $250 \mathrm{~m}$ are strongly weathered.

The Saint-Honore RFeC has strong REE concentrations where the sum of LREE are between 30,000 and 100,000 times the chondrite values and HREE are between 500 and 1000 chondrites (Table 2, Figure 9, Table S1). The REE concentrations do not follow the magmatic evolution trend. Furthermore, no spatial relationship between REE concentration and depth or lateral distance is observed within the $\mathrm{RFeC}$. The upper and deeper zone REE patterns have different $\mathrm{La} / \mathrm{Lu}$ ratio: the upper zone $(250-1000 \mathrm{~m})$ has $(\mathrm{La} / \mathrm{Lu})_{\mathrm{cn}} \approx 460$ and the deeper zone (below $\left.1000 \mathrm{~m}\right)$, has $(\mathrm{La} / \mathrm{Lu})_{\mathrm{cn}} \approx 3100($ Table S1). 
The LREE to HREE ratio is more important at depth. In general, the HREE concentrations of the Saint-Honoré Fe-carbonatite are relatively similar to non-mineralized carbonatites [10], but the LREE are one to two orders of magnitude higher (Figure 9). The REE patterns are strongly fractionated which is typical of REE deposits in carbonatites [8,9,15,59,60]. In general, based on >15,000 REE analyses performed in the RFeC (IAMGold unreleased data), no significant higher-grade zones or vertical variations exist. The mineralization is broadly and homogeneously distributed throughout the Fe-carbonatite.

Table 2. Average REE concentrations and standard deviation of the average for the RFeC.

\begin{tabular}{ccccc}
\hline & \multicolumn{2}{c}{$\begin{array}{c}\text { Upper RFeC } \\
(\mathbf{2 5 0 - 1 0 0 0 ~ m ) ~} \\
\mathbf{N = 3 9}\end{array}$} & \multicolumn{2}{c}{$\begin{array}{c}\text { Lower RFeC } \\
\text { (below 1000 m) } \\
\text { N = 11 }\end{array}$} \\
\hline & Average & Std Dev & Average & Std Dev \\
\hline $\mathrm{La}(\mu \mathrm{g} / \mathrm{g})$ & 4433 & 955 & 6560 & 1963 \\
$\mathrm{Ce}(\mu \mathrm{g} / \mathrm{g})$ & 8528 & 1687 & 11259 & 2927 \\
$\mathrm{Pr}(\mu \mathrm{g} / \mathrm{g})$ & 917 & 165 & 1065 & 266 \\
$\mathrm{Nd}(\mu \mathrm{g} / \mathrm{g})$ & 3054 & 537 & 3215 & 814 \\
$\mathrm{Sm}(\mu \mathrm{g} / \mathrm{g})$ & 323 & 53 & 261 & 79 \\
$\mathrm{Eu}(\mu \mathrm{g} / \mathrm{g})$ & 76 & 14 & 61 & 19 \\
$\mathrm{Gd}(\mu \mathrm{g} / \mathrm{g})$ & 165 & 46 & 113 & 37 \\
$\mathrm{~Tb}(\mu \mathrm{g} / \mathrm{g})$ & 17 & 7.0 & 10.5 & 3.3 \\
$\mathrm{Dy}(\mu \mathrm{g} / \mathrm{g})$ & 55 & 25 & 31 & 10 \\
$\mathrm{Ho}(\mu \mathrm{g} / \mathrm{g})$ & 6.2 & 2.8 & 3.6 & 2.9 \\
$\mathrm{Er}(\mu \mathrm{g} / \mathrm{g})$ & 10.8 & 5.1 & 6.2 & 0.3 \\
$\mathrm{Tm}(\mu \mathrm{g} / \mathrm{g})$ & 1.1 & 0.6 & 0.5 & 1.5 \\
$\mathrm{Yb}(\mu \mathrm{g} / \mathrm{g})$ & 5.7 & 3.2 & 2.3 & 0.2 \\
$\mathrm{Lu}(\mu \mathrm{g} / \mathrm{g})$ & 0.8 & 0.4 & 0.3 & \\
\hline
\end{tabular}

Note: Std Dev = standard deviation of the mean.

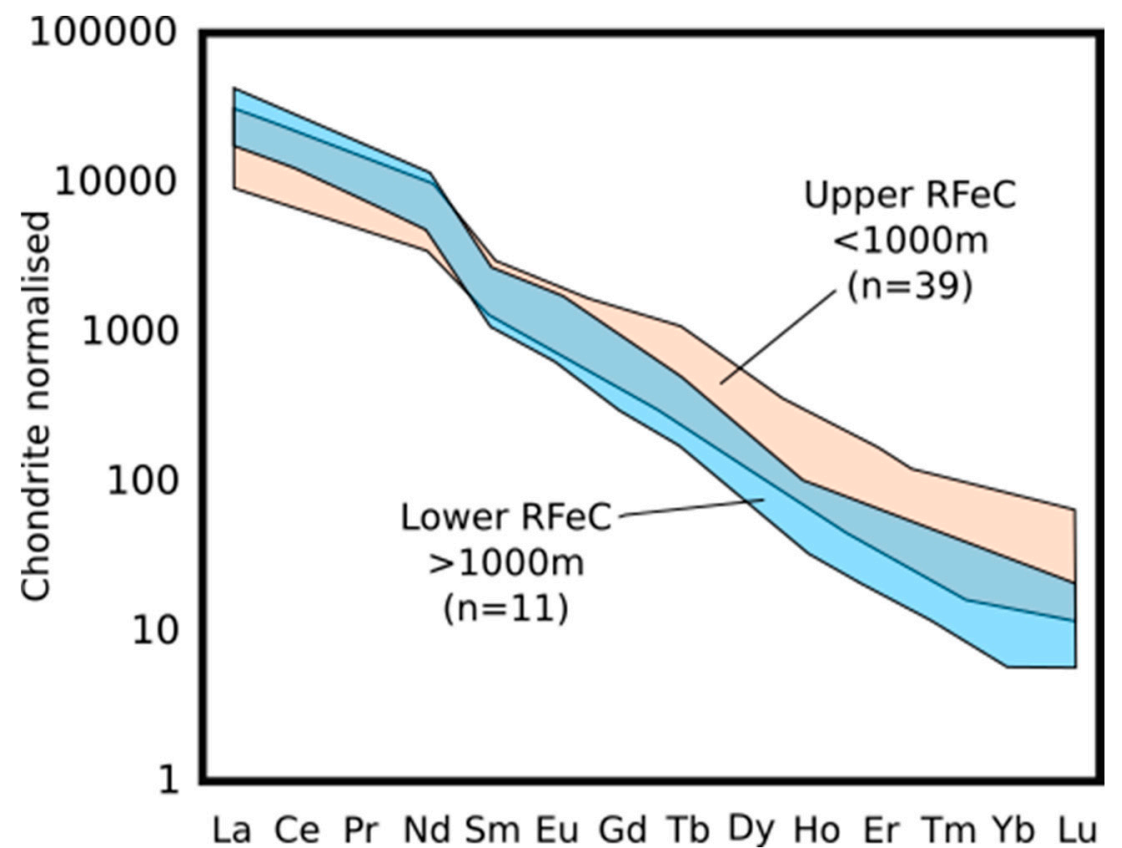

Figure 9. REE patterns (full range) of the upper REE-rich Fe-carbonatite (Upper RFeC-pink) and the lower portion of the REE-rich Fe-carbonatite (Lower RFeC-blue). Chondrite data from McDonough and Sun [61]. 


\section{Discussion}

The magmatic component of carbonatite-hosted REE deposits is, in general, less often described either as it is overprinted by hydrothermal activity or because access to the magmatic evidence is physically difficult. Via numerous drill cores down to $1200 \mathrm{~m}$ below the surface, the Saint-Honoré deposit provides an exceptional access to deeper portions of a REE-bearing Fe-carbonatite. Consequently, observations of the more primitive/pristine units are possible.

The proposed hypothesis that late-stage hydrothermal REE remobilization occurred in the RFeC of Saint-Honoré is supported by a number of observations: (1) hydraulic brecciation; (2) in the breccia, REE minerals are precipitated post-brecciation (for example, the minerals crystalized radially (Figure 4B) from clast edges); (3) the mineralization is associated with minerals typical of hydrothermal REE deposition in carbonatites, such as quartz, hematite, barite and late calcite (Figure 5D); (4) in the late-stage polycrystalline clusters, REE mineralization overprints primary barite and crystallization occurs radially from the barite edges (Figure $4 \mathrm{~B}$ ); (5) mineralization occurred in the form of tiny needles (Figures $4 \mathrm{~B}$ and 5B,D), suggesting a rapid lower-temperature crystallization (Figures 4B and 5B,D); and (6) $\mathrm{La} / \mathrm{Yb}$ ratio are similar to hydrothermal REE deposits such as Bear Lodge (Figure 10) $[59,62]$.

Halite is commonly observed in the dissolution shadow of barite. Halite is also present as deep late-stage veins in Ca- and Mg-carbonatite mined for niobium [63]. Most of the halite observed is late-stage (in polycrystalline clusters, associated with dissolution textures, vein and breccia filling), and interpreted to be related to the hydrothermal activity although halite could have a magmatic origin in the Saint-Honoré Mg-carbonatite as suggested by Kamenetsky et al. [38]. However, subsequent work by Tremblay et al. [63] proposed that halite minute crystals within pyrochlore grains are hydrothermal and $\mathrm{Na}$ comes from pyrochlore alteration. Given that the deposit is overlain by Ordovician limestone, it also could be argued that the halite is of marine origin. However, neither sylvite nor gypsum, typical of seawater infiltration, are present. Furthermore, chlorine is rarely observed in a carbonatite-related fluid. The best example is Ol Doinyo Lengai, which features salt fumaroles [64]. However, fenitization is a clear indication that Na- and/or K-rich fluids were associated with the carbonatites. Furthermore, the existence of halides within the upper part of the $\mathrm{RFeC}$, is probably hidden or lost because of its extreme solubility (e.g. dissolved by meteoric water or during drilling, sampling or thin-section preparation), and most studies have access only to near-surface samples. The experimental data of Williams-Jones et al. [28] suggest that $\mathrm{Cl}^{-}$is an effective ligand for transporting REE in solution. Migdisov and Williams-Jones [65] demonstrated that $\mathrm{Cl}^{-}$as well as sulphate complexes are potent ligands for mobilizing REE as observed in Wicheeta carbonatite [66].

Different sources of REE in carbonatites have been proposed: (1) magmatic REE concentrations in the orthomagmatic fluid generated by fractional crystallization [30]; (2) remobilization of REE leached from primary magmatic minerals, such as carbonates or apatite $[6,15,59,67,68]$ where REE are not an essential constituent (Table S2); and (3) remobilization of REE from early magmatic REE minerals, where REE are essential elements of the minerals from an initially REE-enriched melt [7-9]. To identify the best source model for the Saint-Honoré REE deposit, the most pristine magmatic Fe-carbonatites were identified.

Barite in REE deposits is usually a late-stage mineral precipitated from an orthomagmatic hydrothermal solution [69]. However, the barite of the RFeC presents many lines of evidence for early magmatic crystallization, such as: (1) pseudomorph of early barite by polycrystalline recrystallized barite (Figure 4C,F); (2) clasts of barite in the breccia; and (3) resorption textures in the barite of polycrystalline clusters (Figure 5D). The magmatic crystallization of barite from carbonatite magma is not common, but experimental data demonstrated that this is possible when Ba abundance is high [70,71]. For example, Jones and Wyllie [72] made a glass out of the Mountain Pass carbonatite with over $6 \% \mathrm{Ba}$, thereby demonstrating that such a liquid (carbonate, barite, and La-bearing mineral) is clearly possible. The Mountain Pass deposit, having up to $25 \% \mathrm{BaO}[73,74]$, is a prime example of a Ba-rich carbonatite. Usually, the $\mathrm{BaO} / \mathrm{SrO}$ ratio from $\mathrm{Ca}$-carbonatite to $\mathrm{Fe}$-carbonatite increases from 0.4 to 1, reflecting an increasing $\mathrm{BaO}$ concentration [10,12]. For the Ba-rich Fe-carbonatites of the 
Saint-Honoré carbonatites, the $\mathrm{BaO} / \mathrm{SrO}$ ratio is very high $(>>1)$ because $\mathrm{Sr}$ has not been enriched to the same degree as Ba. Moreover, the Mountain Pass REE deposit is a well-known example of primary euhedral barite crystals in a carbonatite. In the $\mathrm{RFeC}$, the vertical geochemical variation in $\mathrm{Cl}$ and $\mathrm{Ba}$ (Figure 8) appears to reflect the intensity of hydrothermal activity. As mentioned, barite is more soluble in a Cl-rich fluid [55]. The presence of $\mathrm{Cl}$ can be related to the hydrothermal fluids or can be sourced from magmatic activity $[38,63]$. Therefore, the upper part of the deposit, which is rich in $\mathrm{Cl}$ and poor in $\mathrm{Ba}$, could have been exposed to more intense hydrothermal activity, resulting in extensive resorption of primary barite. Inversely, the lower part, which is richer in $\mathrm{Ba}$ and poorer in $\mathrm{Cl}$, is interpreted as a better preserved portion that was exposed to lesser hydrothermal activity. Petrographic observations also support this lower hydrothermal activity in the lower portion of the RFeC: (1) the brecciation is significantly less intense; (2) the crystal sizes are larger; and (3) the barite crystals feature a pristine core and an altered rim (Figure 4C,F). Furthermore, the preliminary results from fluid inclusion gas analyses by solid probe mass spectrometry [75] revealed a progressive decrease in secondary fluid inclusions trapped in carbonates with depth [76]. Moreover, the REE pattern of the deeper zone are typical of magmatic REE deposits such as Mountain Pass (Figure 10) [73,74]. The upper part of the RFeC has a chondrite-normalized REE pattern similar to the Bear Lodge hydrothermal-influenced carbonatite $\left((\mathrm{La} / \mathrm{Lu})_{\mathrm{cn}} \approx 540\right.$ [59]; Figure 10) while the deeper zone of the RFeC has a chondrite-normalized REE pattern more similar to the magmatic Mountain Pass deposit $\left((\mathrm{La} / \mathrm{Lu})_{\mathrm{cn}} \approx 3900\right.$; Figure 10) $[73,74]$.

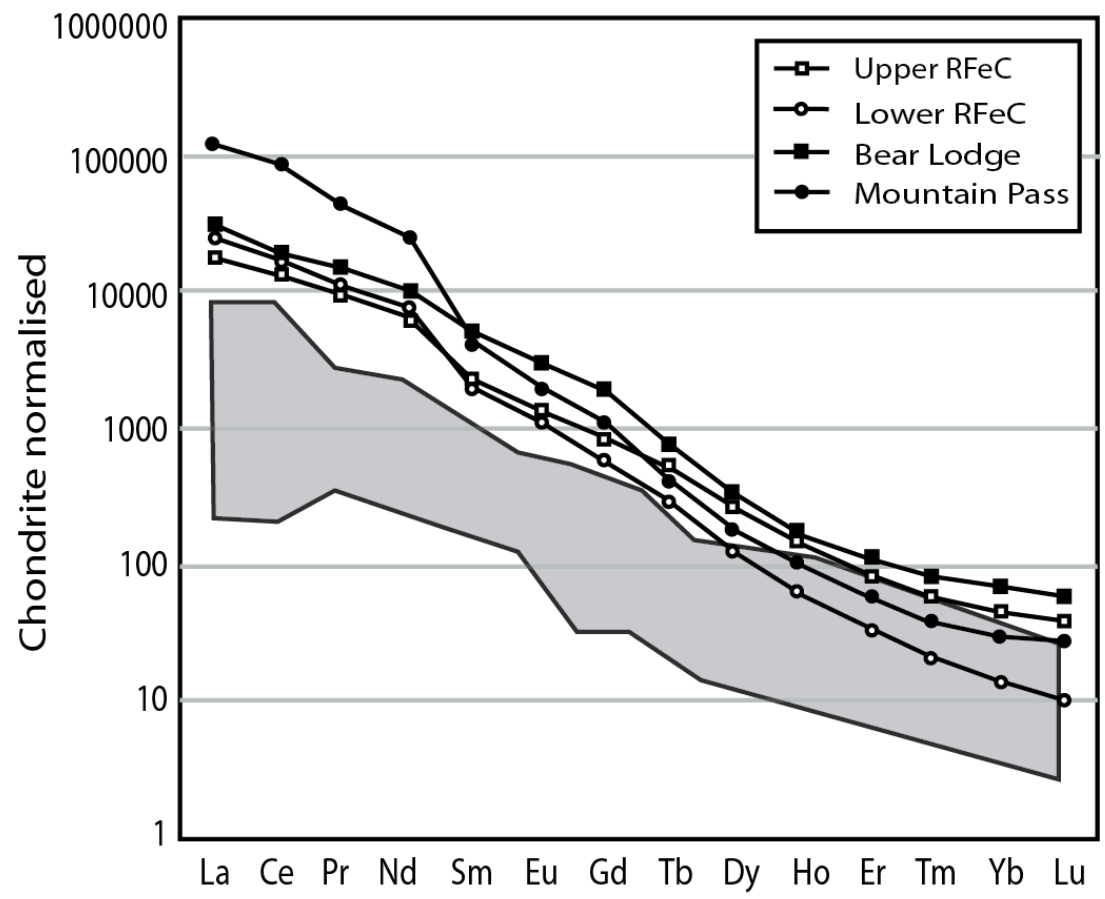

Figure 10. Comparison of the average REE patterns within the upper portion of the REE-rich Fe-carbonatite (Upper RFeC-open squares), the lower portion of the REE-rich Fe-carbonatite (Lower RFeC-open circles), standard carbonatite ([10]-grey zone), magmatic mineralization from Mountain Pass samples ([77]-closed circles) and hydrothermal mineralization from Bear Lodge samples ([59]-closed squares). Chondrite data from McDonough and Sun [61].

As mentioned previously, bastnäsite-(Ce) crystals hosted in primary barite (Figures $4 \mathrm{E}$ and $5 \mathrm{~F}$; Table S2) are observed in the lower part of the RFeC. This occurrence is clearly related to inclusions and not exsolution as: (1) barite and bastnäsite-(Ce) have different crystallographic systems and (2) the orientation of bastnäsite-(Ce) crystals in barite are not parallel to the barite crystal cleavages (Figure 4E). This relationship clearly indicates an early crystallization of magmatic bastnäsite-(Ce). The co-crystallization of REE minerals and barite from a carbonatite magma has already been demonstrated; 
Mountain Pass is probably the best natural example of primary bastnäsite-(Ce) crystals co-occurring with barite [73,74,78]. Experimental studies [14,71,72] have demonstrated the possibility of coeval magmatic barite and REE mineral crystallization with relatively high concentrations of Ba and REE in magma. The principal difference between the RFeC and the PFeC of Saint-Honoré is the presence of both barite and REE minerals. More experimental studies need to be performed to understand the role of barite and the related formation conditions. Despite the dominant interpretation of hydrothermal REE mineralization in carbonatites, early magmatic crystallization of REE minerals could be an important process in generating world-class carbonatite-hosted REE deposits. Song et al. [79] show that $\mathrm{REE}, \mathrm{Ba}, \mathrm{Sr}, \mathrm{Mo}$, and $\mathrm{W}$ will partition strongly in the carbonatitic within magma rather than within fluid, hence suggesting that a magmatic stage is probably more important than previously recognized. A magmatic stage could even be the precursor to many hydrothermal REE deposits, given that their deeper portions are often not accessible for documenting such processes.

From a petrogenetic perspective, Girnis et al. [80] studied the experimental partitioning of selected trace elements between mantle minerals and silico-carbonate melts at 6-12 GPa and 1300-1700 ${ }^{\circ} \mathrm{C}$. They show that high $\mathrm{La} / \mathrm{Lu}$ and $\mathrm{BaO} / \mathrm{SrO}$ ratios can be produced by a low primary mantle melting ratio as LREE and $\mathrm{BaO}$ are more incompatible than HREE and $\mathrm{SrO}$ in mantle minerals. Such processes could have led to the primary carbonatite magmas that afterward differentiated to produce the LREE and $\mathrm{BaO}$ rich Fe-carbonatite as it could have been the case in the Saint-Honoré deposit.

The observations presented in this study significantly improve the ore genesis model of the Saint-Honoré REE deposit. First, the carbonatite complex evolves from Ca-carbonatite to Fe-carbonatite by crystal fractionation, concentrating incompatible elements, such as REE, in the late-stage of Fe-carbonatite formation. During the crystallization of the Fe-carbonatite, the concentrations of both REE and barite continuously increase in the residual liquid until the point of oversaturation, at which point bastnäsite-(Ce) and barite begin to crystallize. Depending on the activity of $\mathrm{PO}_{4}$, monazite-(Ce) may also crystalize at this stage, however no primary monazite-(Ce) was observed. In the Saint-Honoré complex, the combination of initial low partial melting of the mantle, crystal fractionation and partitioning of REE in the magma instead of the fluid could explain this high concentration of REE and Ba during the magmatic stage. A late-stage fluid, probably orthomagmatic and rich in $\mathrm{SiO}_{2}, \mathrm{FeO}, \mathrm{H}_{2} \mathrm{O}, \mathrm{CO}_{2}$, and $\mathrm{Cl}$, dissolves the primary $\mathrm{REE}$ minerals and enriches the REE in solution. The initial Fe-carbonatite exhibits evidence of hydrothermal fluid-induced cracking of the primary carbonatite up to the total breakdown in the form of a hydraulic breccia. This hydrothermal brecciation induces spontaneous decreases in pressure and causes the crystallization of tiny needles of REE minerals around clasts and partially dissolved minerals such as barite. Finally, the upper part of the Fe-carbonatite, post-magmatic, is partially leached by surficial (meteoric or marine) water, evidenced by the absence of halite and barite in the uppermost zone and, more extensively, by the strong near-surface weathering. The precipitation of barite, the interactions with carbonates and the crystallization of apatite (Table S2) are all important mechanisms that precipitate REE minerals, such as fluoro-carbonates and monazite-(Ce). These three mechanisms are present in the Saint-Honoré REE deposit and probably played key roles in the hydrothermal precipitation of REE mineralization.

\section{Conclusions}

In earlier studies, the REE mineralization at Saint-Honoré has been interpreted to be purely hydrothermal. In this study, access to deeper portions of the carbonatite provided crucial evidence showing magmatic crystallization of bastnäsite-(Ce). Considering the REE distribution is associated with hydrothermal mineralization, the early magmatic crystallization appears critical to generate larger deposits and larger REE crystals which are more profitable to exploit.

Furthermore, the crystallization of primary barite appears to be an important indication of magmatic crystallization of REE minerals. This study and other experiments indicate that carbonatitic magma rich in $\mathrm{Ba}$ and REE will crystallize barite and REE minerals. More specific experiments should be conducted to understand whether the concentration of Ba positively affects the solidus of REE 
minerals or whether the concentration of $\mathrm{Ba}$ is a proxy for the concentration of REE in the magma or a combination of both. For future exploration, the presence of primary barite in a carbonatite can be considered to be a good indicator of the carbonatite potential for hosting significant REE deposits.

Supplementary Materials: The following are available online at http:/ /www.mdpi.com/2075-163X/8/9/397/s1, Table S1: Results for whole rock geochemical analyses. Table S2: Representative REE results in $\mu \mathrm{g} / \mathrm{g}$ for apatite, carbonates and barite by LA-ICP-MS.

Author Contributions: Conceptualization, L.P.B. and D.G.; Methodology, L.P.B.; Validation, L.P.B. and D.G..; Formal Analysis, A.N.; Investigation, A.N., L.P.B., and D.G.; Writing-Original Draft Preparation, A.N.; Writing-Review \& Editing, A.N., L.P.B., and D.G.; Supervision, L.P.B. and D.G.; Project Administration, L.P.B.; Funding Acquisition, L.P.B. and D.G.

Funding: The project was financed by a NSERC-CRD grant to L.P. Bédard and D. Gaboury as well as Lucien Bouchard and CEGER fellowships to A. Néron.

Acknowledgments: Discussions with Guillaume Matton, Jean-François Tremblay, and Louis Grenier (Niobec Inc.) greatly improved our understanding of the deposit. Sadia Mehdi and Dany Savard (LabMaTer Univ. Québec à Chicoutimi) are thanked for their outstanding help on the LA-ICP-MS. Valérie Lecompte (IOS Services Géoscientifiques Inc.) and Zhang Zhan (CURAL, Univ. Québec à Chicoutimi) helped with the SEM. Yvon Boudreault prepared some of the polished thin sections for the halite-bearing samples. Jean-François Boivin (IOS Services Géoscientifiques Inc.) is thanked for his help during core logging. Steve Wilson (USGS) provided a reference material from the Mountain Pass deposit (CMP-1). We thank the referees for their helpful suggestions that improved substantially this manuscript.

Conflicts of Interest: The authors declare no conflict of interest.

\section{References}

1. Simandl, G. Geology and market-dependent significance of rare earth element resources. Miner. Depos. 2014, 49, 889-904. [CrossRef]

2. Goodenough, K.M.; Wall, F.; Merriman, D. The rare earth elements: Demand, global resources, and challenges for resourcing future generations. Nat. Resour. Res. 2018, 27, 201-216. [CrossRef]

3. Rollat, A.; Guyonnet, D.; Planchon, M.; Tuduri, J. Prospective analysis of the flows of certain rare earths in Europe at the 2020 horizon. Waste Manag. 2016, 49, 427-436. [CrossRef] [PubMed]

4. Guyonnet, D.; Planchon, M.; Rollat, A.; Escalon, V.; Tuduri, J.; Charles, N.; Vaxelaire, S.; Dubois, D.; Fargier, H. Material flow analysis applied to rare earth elements in Europe. J. Clean. Prod. 2015, 107, 215-228. [CrossRef]

5. Weng, Z.; Jowitt, S.M.; Mudd, G.M.; Haque, N. A detailed assessment of global rare earth element resources: Opportunities and challenges. Econ. Geol. 2015, 110, 1925-1952. [CrossRef]

6. Chakhmouradian, A.R.; Wall, F. Rare earth elements: Minerals, mines, magnets (and more). Elements 2012, 8, 333-340. [CrossRef]

7. Smith, M.; Moore, K.; Kavecsánszki, D.; Finch, A.A.; Kynicky, J.; Wall, F. From mantle to critical zone: A review of large and giant sized deposits of the rare earth elements. Geosci. Front. 2016, 7, 315-334. [CrossRef]

8. Verplanck, P.L.; Mariano, A.N.; Mariano, A., Jr. Rare earth element ore geology of carbonatites. In Rare Earth and Critical Elements in Ore Deposits; Verplanck, P.L., Hitzman, M.W., Eds.; Society of Economic Geologists: Golden, CO, USA, 2016; Volume 18, pp. 5-32.

9. Chakhmouradian, A.R.; Zaitsev, A.N. Rare earth mineralization in igneous rocks: Sources and processes. Elements 2012, 8, 347-353. [CrossRef]

10. Woolley, A.R.; Kempe, D.R.C. Carbonatites: Nomenclature, average chemical compositions, and element distribution. In Carbonatites: Genesis and Evolution; Unwin Hyman: London, UK, 1989; pp. 1-14.

11. Nelson, D.; Chivas, A.; Chappell, B.; McCulloch, M. Geochemical and isotopic systematics in carbonatites and implications for the evolution of ocean-island sources. Geochim. Cosmochim. Acta 1988, 52, 1-17. [CrossRef]

12. Heinrich, E.W. The Geology of Carbonatites; Rand McNally: Chicago, IL, USA, 1966.

13. Woolley, A.R.; Kjarsgaard, B.A. Paragenetic types of carbonatite as indicated by the diversity and relative abundances of associated silicate rocks: Evidence from a global database. Can. Mineral. 2008, 46, 741-752. [CrossRef]

14. Jones, A.P.; Wyllie, P.J. Solubility of rare earth elements in carbonatite magmas, indicated by the liquidus surface in $\mathrm{CaCO}_{3}-\mathrm{Ca}(\mathrm{OH})_{2}-\mathrm{La}(\mathrm{OH})_{3}$; at 1 kbar pressure. Appl. Geochem. 1986, 1, 95-102. [CrossRef] 
15. Mariano, A.N. Nature of economic mineralization in carbonatites and related rocks. In Carbonatites: Genesis and Evolution; Unwin Hyman: London, UK, 1989; pp. 149-176.

16. Doroshkevich, A.G.; Ripp, G.S.; Viladkar, S.G.; Vladykin, N.V. The Arshan REE carbonatites, southwestern transbaikalia, russia: Mineralogy, paragenesis and evolution. Can. Mineral. 2008, 46, 807-823. [CrossRef]

17. Martin, L.H.J.; Schmidt, M.W.; Mattsson, H.B.; Guenther, D. Element partitioning between immiscible carbonatite and silicate melts for dry and $\mathrm{H}_{2} \mathrm{O}$-bearing systems at 1-3 GPa. J. Petrol. 2013, 54, 2301-2338. [CrossRef]

18. Kjarsgaard, B.; Hamilton, D.; Peterson, T. Peralkaline nephelinite/carbonatite liquid immiscibility: Comparison of phase compositions in experiments and natural lavas from oldoinyo lengai. In Carbonatite Volcanism; Springer Nature: Berlin/Heidelberg, Germany, 1995; pp. 163-190.

19. Gittins, J. The origin and evolution of carbonatite magmas. In Carbonatites: Genesis and Evolution; Bell, K., Ed.; Unwin Hyman: London, UK, 1989; pp. 580-600.

20. Kjarsgaard, B.; Hamilton, D. The genesis of carbonatites by immiscibility In Carbonatites: Genesis and Evolution; Bell, K., Ed.; Unwin Hyman: London, UK, 1989; pp. 388-404.

21. Le Bas, M.J. Diversification of carbonatite. In Carbonatites: Genesis and Evolution; Bell, K., Ed.; Unwin Hyman: London, UK, 1989; pp. 105-141.

22. Kjarsgaard, B.A.; Hamilton, D.L. Liquid immiscibility and the origin of alkali-poor carbonatites. Mineral. Mag. 1988, 52, 43-55. [CrossRef]

23. Von Eckermann, H. The Alkaline District of Alnö Island (Alnö Alkalina Område); A. b. Kartografiska institutet: Stockholm, Sweden, 1948.

24. Torro, L.; Villanova, C.; Castillo, M.; Campeny, M.; Gonçalves, A.O.; Melgarejo, J.C. Niobium and rare earth minerals from the Virulundo carbonatite, Namibe, Angola. Mineral. Mag. 2012, 76, 393-409. [CrossRef]

25. Ruberti, E.; Enrich, G.E.; Gomes, C.B.; Comin-Chiaramonti, P. Hydrothermal REE fluorocarbonate mineralization at Barra do Itapirapua, a multiple stockwork carbonatite, Southern Brazil. Can. Mineral. 2008, 46, 901-914. [CrossRef]

26. Melgarejo, J.C.; Costanzo, A.; Bambi, A.C.J.M.; Gonçalves, A.O.; Neto, A.B. Subsolidus processes as a key factor on the distribution of $\mathrm{Nb}$ species in plutonic carbonatites: The Tchivira case, Angola. Lithos 2012, 152, 187-201. [CrossRef]

27. Verplanck, P.L. The role of fluids in the formation of rare earth element deposits. Procedia Earth Planet. Sci. 2017, 17, 758-761. [CrossRef]

28. Williams-Jones, A.E.; Migdisov, A.A.; Samson, I.M. Hydrothermal mobilisation of the rare earth elements-a tale of "ceria" and "yttria". Elements 2012, 8, 355-360. [CrossRef]

29. Gauthier, A. Étude Minéralogique, Pétrographique et Géochimique de la Zone à Terres Rares de la Carbonatite de St-Honoré. Master's Thesis, Université du Québec à Chicoutimi, Chicoutimi, QC, Canada, 1979.

30. Fournier, A. Magmatic and Hydrothermal Controls of LREE Mineralization of the St-Honoré Carbonatite. Master's Thesis, McGill University, Montreal, QC, Canada, 1993.

31. Grenier, L.; Tremblay, J.-F.; Sirois, R. Updated Mineral Resource Estimate for Rare Earth Elements; NI-43-101 Technical Report; IAMGold Corporation: Toronto, ON, Canada, 2013; p. 166.

32. Higgins, M.D.; Van Breemen, O. Three generations of Anorthosite-Mangerite-Charnockite-Granite (AMCG) magmatism, contact metamorphism and tectonism in the Saguenay-Lac-Saint-Jean region of the Grenville province, Canada. Precambrian Res. 1996, 79, 327-346. [CrossRef]

33. Dimroth, E.; Woussen, G.; Roy, D.W. Geologic history of the Saguenay region, Quebec (central granulite terrain of the Grenville province): A working hypothesis. Can. J. Earth Sci. 1981, 18, 1506-1522. [CrossRef]

34. Kumarapeli, P.; Saull, V.A. The St. Lawrence valley system: A North American equivalent of the East African rift valley system. Can. J. Earth Sci. 1966, 3, 639-658. [CrossRef]

35. Vallée, M.; Dubuc, F. St-Honoré carbonatite complex. Quebec. Can. Inst. Min. Metall. Bull. 1970, 73, $346-356$.

36. Doig, R.; Barton, J.M., Jr. Ages of carbonatites and other alkaline rocks in Quebec. Can. J. Earth Sci. 1968, 5, 1401-1407. [CrossRef]

37. McCausland, P.; Pisarevsky, S.; Jourdan, F.; Higgins, M. Laurentia at 571 ma: Preliminary paleomagnetism and Ar-Ar age of the ediacaran St. Honore alkali intrusion, Quebec. In Proceedings of the American Geophysical Union-Geological Association of Canada-Mineralogical Association of Canada-Canadian Geophysical Union (CGU) Joint Assembly, Toronto, ON, Canada, 24-27 May 2009. GA12A-01. 
38. Kamenetsky, V.S.; Mitchell, R.H.; Maas, R.; Giuliani, A.; Gaboury, D.; Zhitova, L. Chlorine in mantle-derived carbonatite melts revealed by halite in the St-Honoré intrusion (Québec, Canada). Geology 2015, 43, 687-690. [CrossRef]

39. Hébert, C. Géologie De La Région De Chicoutimi; SI-22D-C2G-00K; Ministère des Ressources Naturelles du Québec: Québec, QC, Canada, 2000.

40. Fortin-Bélanger, M. Le Complexe Annulaire à Carbonatites De St-Honoré (PQ, Canada) et sa Minéralisation à Niobium: Étude Pétrographique et Géochimique. Ph.D. Thesis, Université Claude Bernard, Lyon, France, 1977.

41. Bédard, L.P.; Barnes, S.-J. How fit are your data. Geostand. Geoanal. Res. 2010, 34, 275-280. [CrossRef]

42. Green, T.; Adam, J.; Siel, S. Trace element partitioning between silicate minerals and carbonatite at $25 \mathrm{kbar}$ and application to mantle metasomatism. Mineral. Petrol. 1992, 46, 179-184. [CrossRef]

43. Bédard, L.P.; Savard, D.; Barnes, S.-J. Total sulfur concentration in geological reference materials by elemental infrared analyser. Geostand. Geoanal. Res. 2008, 32, 203-208. [CrossRef]

44. Govindaraju, K. Compilation of working values and sample description for 383 geostandards. Geostand. Newslett. 1994, 18, 1-158. [CrossRef]

45. Norman, M.D.; Pearson, N.J.; Sharma, A.; Griffin, W.L. Quantitative analysis of trace elements in geological materials by laser ablation ICPMS: Instrumental operating conditions and calibration values of nist glasses. Geostand. Newslett. 1996, 20, 247-261. [CrossRef]

46. Wise, S.A.; Watters, R.L., Jr. Certificate of Analysis Standard Reference Material 610; Trace Elements in Glass; National Institute of Standard and Technology: Gaithersburg, MD, USA, 2009; p. 4.

47. Jochum, K.P.; Stoll, B.; Weis, U.; Jacob, D.E.; Mertz-Kraus, R.; Andreae, M.O. Non-matrix-matched calibration for the multi-element analysis of geological and environmental samples using $200 \mathrm{~nm}$ femtosecond LA-ICP-MS: A comparison with nanosecond lasers. Geostand. Geoanal. Res. 2014, 38, 265-292. [CrossRef]

48. Jochum, K.P.; Scholz, D.; Stoll, B.; Weis, U.; Wilson, S.A.; Yang, Q.; Schwalb, A.; Börner, N.; Jacob, D.E.; Andreae, M.O. Accurate trace element analysis of speleothems and biogenic calcium carbonates by LA-ICP-MS. Chem. Geol. 2012, 318, 31-44. [CrossRef]

49. Wilson, S. USGS microanalytical reference materials (MRMS) development. Microsc. Microanal. 2017, 23, 492-493. [CrossRef]

50. Guillong, M.; Hametner, K.; Reusser, E.; Wilson, S.A.; Günther, D. Preliminary characterisation of new glass reference materials (gsa-1g, gsc-1g, gsd-1g and gse-1g) by laser ablation-inductively coupled plasma-mass spectrometry using $193 \mathrm{~nm}, 213 \mathrm{~nm}$ and $266 \mathrm{~nm}$ wavelengths. Geostand. Geoanal. Res. 2005, 29, 315-331. [CrossRef]

51. Tremblay, L.M. Caractérisation Pétrographique et Géochimique de la Baryte de la Zone à Terres Rares du Complexe Alcalin de Saint-Honoré-Développement d'une Méthode D'analyse par LA-ICP-MS pour les Éléments Traces Appliquée à la Baryte. Bachelor's Thesis, Université du Québec à Chicoutimi, Chicoutimi, QC, Canada, 2013.

52. Jochum, K.P.; Nohl, U.; Herwig, K.; Lammel, E.; Stoll, B.; Hofmann, A.W. Georem: A new geochemical database for reference materials and isotopic standards. Geostand. Geoanal. Res. 2005, 29, 333-338. [CrossRef]

53. Hellstrom, J.; Paton, C.; Woodhead, J.; Hergt, J. Iolite: Software for spatially resolved LA-(quad and mc) ICPMS analysis. Mineral. Assoc. Can. Short Course Ser. 2008, 40, 343-348.

54. Paton, C.; Hellstrom, J.; Paul, B.; Woodhead, J.; Hergt, J. Iolite: Freeware for the visualisation and processing of mass spectrometric data. J. Anal. At. Spectrom. 2011, 26, 2508-2518. [CrossRef]

55. Blount, C. Barite solubilities and thermodynamic quantities up to $300^{\circ} \mathrm{C}$ and 1400 bars. Am. Mineral. 1977, 62, 942-957.

56. Wall, F.; Mariano, A. Rare earth minerals in carbonatites: A discussion centred on the Kangankunde carbonatite, Malawi. In Rare Earth Minerals: Chemistry, Origin and Ore Deposit; Jones, A.P., Wall, F., Williams, C.T., Eds.; Springer: Heidelberg, Germany, 1996; Volume 7, pp. 193-226.

57. Jébrak, M. Hydrothermal breccias in vein-type ore deposits: A review of mechanisms, morphology and size distribution. Ore Geol. Rev. 1997, 12, 111-134. [CrossRef]

58. Gittins, J.; Harmer, R.E. What is ferrocarbonatite? A revised classification. J. Afr. Earth Sci. 1997, 25, $159-168$. [CrossRef] 
59. Moore, M.; Chakhmouradian, A.R.; Mariano, A.N.; Sidhu, R. Evolution of rare-earth mineralization in the Bear Lodge carbonatite, Wyoming: Mineralogical and isotopic evidence. Ore Geol. Rev. 2015, 64, 499-521. [CrossRef]

60. Mariano, A.N. Economic geology of rare earth elements. Rev. Mineral. Geochem. 1989, 21, 309-337.

61. McDonough, W.F.; Sun, S.-S. The composition of the earth. Chem. Geol. 1995, 120, 223-253. [CrossRef]

62. Andersen, A.K.; Clark, J.G.; Larson, P.B.; Donovan, J.J. REE fractionation, mineral speciation, and supergene enrichment of the Bear Lodge carbonatites, Wyoming, USA. Ore Geol. Rev. 2017, 89, 780-807. [CrossRef]

63. Tremblay, J.; Bédard, L.P.; Matton, G. Columbitization of fluorcalciopyrochlore by hydrothermalism at the Saint-Honoré alkaline complex, Québec (Canada): New insights on halite in carbonatites. Ore Geol. Rev. 2017, 91, 695-707. [CrossRef]

64. Genge, M.; Balme, M.; Jones, A. Salt-bearing fumarole deposits in the summit crater of Oldoinyo Lengai, northern Tanzania: Interactions between natrocarbonatite lava and meteoric water. J. Volcanol. Geotherm. Res. 2001, 106, 111-122. [CrossRef]

65. Migdisov, A.; Williams-Jones, A.E. Hydrothermal transport and deposition of the rare earth elements by fluorine-bearing aqueous liquids. Miner. Depos. 2014, 49, 1-11. [CrossRef]

66. Trofanenko, J.; Williams-Jones, A.E.; Simandl, G.J.; Migdisov, A.A. The nature and origin of the REE mineralization in the Wicheeda carbonatite, British Columbia, Canada. Econ. Geol. 2016, 111, 199-223. [CrossRef]

67. Deans, T. Economic mineralogy of african carbonatites. In Carbonatites; Tuttle, O.F., Gittins, J., Eds.; Wiley: New York, NY, USA, 1966; pp. 358-413.

68. Andrade, F.; Möller, P.; Lüders, V.; Dulski, P.; Gilg, H.A. Hydrothermal rare earth elements mineralization in the Barra do Itapirapua carbonatite, southern Brazil: Behaviour of selected trace elements and stable isotopes (c, o). Chem. Geol. 1999, 155, 91-113. [CrossRef]

69. Heinrich, E.W.; Vian, R. Carbonatitic barites. Am. Mineral. J. Earth Planet. Mater. 1967, 52, 1179-1189.

70. Jones, A.P.; Genge, M.; Carmody, L. Carbonate melts and carbonatites. Rev. Mineral. Geochem. 2013, 75, 289-322. [CrossRef]

71. Kuellmer, F.; Visocky, A.; Tuttle, O. Preliminary survey of the system barite-calcite-fluorite at 500 bars. In Carbonatites; Tuttle, O.F., Gittins, J., Eds.; Wiley: New York, NY, USA, 1966; pp. 353-364.

72. Jones, A.P.; Wyllie, P.J. Low-temperature glass quenched from a synthetic, rare earth carbonatite; implications for the origin of the Mountain Pass deposit, California. Econ. Geol. 1983, 78, 1721-1723. [CrossRef]

73. Castor, S.B. The Mountain Pass rare-earth carbonatite and associated ultrapotassic rocks, California. Can. Mineral. 2008, 46, 779-806. [CrossRef]

74. Olson, J.C.; Pray, L.C. The Mountain Pass rare earth deposits. Calif. Div. Mines Bull. 1954, 170, $23-29$.

75. Gaboury, D.; Keita, M.; Guha, J.; Lu, H.-Z. Mass spectrometric analysis of volatiles in fluid inclusions decrepitated by controlled heating under vacuum. Econ. Geol. 2008, 103, 439-443. [CrossRef]

76. Néron, A. Caractérisation de la Minéralisation de la Zone à Terres Rares de la Carbonatite de Saint-Honoré, Québec, Canada. Master' Thesis, Université du Québec à Chicoutimi, Chicoutimi, QC, Canada, 2013.

77. Haxel, G. Ultrapotassic mafic dikes and rare earth elements-and barium-rich carbonatite at Mountain Pass, Mojave Desert, Southern California: Summary and field trip localities. In U.S. Geological Survey; USGS publications: Reston, VA, USA, 2005.

78. Poletti, J.E.; Cottle, J.M.; Hagen-Peter, G.A.; Lackey, J.S. Petrochronological constraints on the origin of the Mountain Pass ultrapotassic and carbonatite intrusive suite, California. J. Petrol. 2016, 57, 1555-1598. [CrossRef]

79. Song, W.; Xu, C.; Veksler, I.; Kynicky, J. Experimental study of REE, Ba, Sr, Mo and W partitioning between carbonatitic melt and aqueous fluid with implications for rare metal mineralization. Contrib. Mineral. Petrol. 2015, 171, 1-12. [CrossRef]

80. Girnis, A.; Bulatov, V.; Brey, G.; Gerdes, A.; Höfer, H. Trace element partitioning between mantle minerals and silico-carbonate melts at 6-12 gpa and applications to mantle metasomatism and kimberlite genesis. Lithos 2013, 160, 183-200. [CrossRef]

(C) 2018 by the authors. Licensee MDPI, Basel, Switzerland. This article is an open access article distributed under the terms and conditions of the Creative Commons Attribution (CC BY) license (http://creativecommons.org/licenses/by/4.0/). 